\title{
地方自治体における統合環境負荷推計ツール 開発と滋賀県への適用
}

\author{
五味 馨 1 島田 幸司 2 ・松岡 譲 3 \\ 1 学生会員 京都大学大学院地球環境学舎博士後期課程 (T606-8501 京都市左京区吉田本町) \\ E-mail: g.kei@iwyh.media.mbox.kyoto-u.ac.jp \\ ${ }^{2}$ 正会員 博士(工学) 立命館大学経済学部教授 (广525-8577 滋賀県草津市野路東 1-1-1) \\ ${ }^{3}$ 正会員 工学博士 京都大学大学院地球環境学堂教授 (T 606-8501 京都市左京区吉田本町)
}

\begin{abstract}
地方自治体が効果的に環境問題に取り組むには, 数十年にわたる定量的な情報が必要である. 本研究では, 都道 府県や都市を対象として, 将来の社会·経済の状態と環境負荷発生量を整合的に推計するツ一ルを開発する. 将来社 会の想定に基づいて産業生産額や交通需要などの社会経済指標を推計し, それと利用技術等から環境負荷発生量を 推計する. 複数の環境負荷を同一の枠組みで取り扱うことにより, 対象地域の直面する様々な課題に総合的に対応する. さらに, 具体例として滋賀県へ適用し, 温室効果ガス, 水質污濁負荷, 廃棄物について, 2030年にそれぞれの排出目標 を達成した状態を示した. このツールは, 長期の環境計画策定において, より効率的かつ効果的な議論の一助となる.
\end{abstract}

Key Words: local environmental policy, long-term planning, low carbon society, integrated evaluation

\section{1.はじめに}

地方自治体は様々な環境問題の解決にあたって重要な 役割を果たす. 大気や水質の污染のような局地的な問題だ けでなく, 気候変動のような地球規模の問題であっても対策 の具体的な実施段階では地域ごとの行動が必要である.こ れらの問題には長期にわたるものも多く, 効果的な行動には 数十年といった長期の計画が必要である.また, しばしば複 数の環境の目標を同時に達成されることも求められる. 長期 においては大幅な社会変革がありえるから, 計画の策定には 社会や経済の状況と種々の環境負荷発生に関する定量的 な情報が必要となる. そして, そのような計画の中では, 目標 とする地域の将来像を示すことが第一に必要と考えられる.

国レベルの研究では, 脱温暖化 2050 研究プロジェ外) 2) が, 2050 年の日本においてエネルギー起源の二酸化炭素 排出量を 1990 年比で 70\%削減した状態を推計している. 人 ロ・世帯推計モデル, 応用一般均衡モデル, 住宅モデル, 交通需要モデルなどを開発し, 社会の各側面について詳細 な推計を行っている.ここで開発されている大規模なモデル 群による推計手法は整合性や具体性に優れる. しかし, デー タの入手可能性などから, 都道府県や都市などには必ずしも 適切でない.

諸国の都市や州の中には独自の長期(2020 年以降)の気
候変動に関する目標を掲げているものがあり, そのうちいくつ かは定量的な評価を行っている(500798910).このうちカリフオル ニア州》は非常に経済規模が大きく(人口約 3700 万人, GDP はイ夘ア並み), ここでいら「地方自治体かか除外する. そこ で他の推計の内容をみると,「社会像」たりえていないといら問 題がある. すなわち単純に排出削減対策の組み合わせを示 すにとどまっており, 将来の社会経済の推定方法(人口, 生 産額, 輸送需要など)に問題がある. 多くはそれぞれトレンドを 外挿しており, 指標間の整合性を欠く可能性が高い. そのた めここで考える「目標とする地域の将来像」とは言い難い.

これらの問題点に接近した先行研究しして, 島田ら ${ }^{3)}$ の研 究が挙げられる.この研究では滋賀県を対象としてマクロ経 済財政モデル, 産業連関分析, 交通需要量推計モデル, エ ネルギー需要量推計モデルなどを組み合わせ, 各部門の活 動量を整合的に推計し, 2030 年においてエネルギ一起源の 一酸化炭素排出量を 1990 年比で 30-50\%削減するシ十少才 を構築した. しかしここでは, いつかの重要な変数を簡易な 手法で推計しており, 将来社会の変化の想定を十分反映で きていない.また対象ししている環境負荷が二酸化炭素だけ である.

そこで本研究では, 地方自治体を対象とし, 長期環境計 画の目標としての, 社会·経済と環境に関する定量的な将来 
像を表現する手法を開発する.これまでの手法3)を拡張・精 緻化する形で, 社会·経済·環境の各側面の諸量を, 定量的 かつ整合的に表現する推計ツール(以下, スナップショットツ ールと称する)を開発する.

拡張·精緻化の内容は次の各点である. (1)複数の環境負 荷を推計する同一の枠組みを開発する. (2)生活時間の推計 を加える. (3)労働生産性を明示的に扱い, 生活時間との整 合性を確保する. (4)これまでに一括で推計していた業務部 門の床面積)を業種別に推計する. (5)同じく貨物輸送量を積
荷別に推計する. (6)旅客輸送量の推計にあたって個人属性 に免許保有の有無を加える. (7)家畜飼養頭羽数を推計に加 える. 8)これら全体を整合的に推計する単一の計算プログラ ムを開発する.これらの拡張により, 様々な状況, 想定に応じ た推計が可能となる.

また, 推計の具体例として滋賀県へと本ツールを適用する. その際にスナップショットツールの入力として必要な最終需要 を推計するため, 滋賀県マク口計量経済モデルも開発する. - 目標年, 環境の目標, 対象範囲, 対象活動, etc.

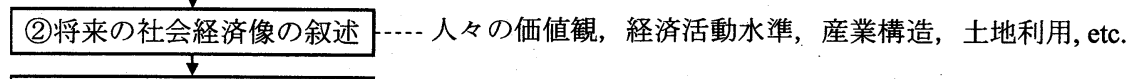

(3)環境対策リストの整備 -...- 利用技術, 社会基盤整備, 環境配慮行動, etc.

(4)スナップショットツール による定量化

(5)環境対策の同定

(6)環境対策を誘導するため の政策を提案
社会経済指標，環境負荷排出量,

利用技術，交通構造，社会基盤，環境配慮行動, etc.

図-1 手法全体の流れ

\section{2. 手法の全体}

図一1に本研究で開発した手法全体の手順を示す.

(1)まず目標と枠組みを設定する. 対象地域, 目標年, 対 象とする活動の範囲, 環境負荷の種類とその目標などを決 定する. 対象地域については, 通常, 対象とする地方自治体 の統治が及ぶ範囲となるであろう. 従って当該地方自治体の 住民の活動であっても, その圈域外での活動は含まれない.

(2) 次に将来の社会経済像を定性的に叙述する. 社会全 体の発展の方向を左右する人々の価值観や, 経済活動水 準, 産業構造, 土地利用など, 関係する各側面の将来にお ける様相を想定する. この想定は一つとは限らず, 研究の目 的や文脈に応じて複数の社会経済像(例えば SRES の 4 つ のシナ少オ゙少を想定することがありえる.

(3) 環境対策を収集, 整備する. 対象地域で目標年におい て利用可能と考えられる技術, 社会基盤, 環境配慮行動など からなる. スナップショットツールへの入力とするため, 定量的 な情報が必要である.

(4)スナップショットツールを利用し, (2)で想定した社会像を 定量的に表現する. スナップショットツールの入力となる変 数.係数の具体的な值を(2)の想定に基づいて設定し, 各種 の社会経済指標と環境負荷排出量を推計する(詳しい推計 の内容は後述).
(5) (3)の推計結果から, 環境の目標を達成するために必要 な環境対策の組み合わせを同定する. 目標の水淮によって は, それを達成する対策の組み合わせが複数ある場合や, 逆に利用可能な全ての対策を導入しても達成できないといら ことがありえる. 前者の場合は何らかの基淮(費用最小化など) によって決定する. 後者の場合は, 目標の見直し,さらなる対 策の可能性検討, いかなる社会経済像であれば達成可能か, といらた議論へとつながる。

(6) 同定された環境の対策を実現するための政策パツケー ジを提案する.これは地方自治体にとって実行可能な政策 でなくてはならず, 経済的インセンティブ(税制や補助金, 金 融など), 各種の規制(土地利用規制など), 社会基盤整備(気 候変動対策であれば公共交通機関の整備など)などがありえ る.

\section{3. 滋賀県マク口計量経済モデルの開発}

手法(2)の「経済活動水準」を得るため, 本研究では県マク 口計量経済モデルを開発した. その構造を図-2に示す. 内生 変数 15 個, 外生変数 9 個のコンパクトなモデルである. 県の 経済は国全体の動向を含む需要の水淮に左右される傾向 が大きいと考え, GDP は需要決定型とした. なお, 金額を示 す変数は全て実質価格である. 


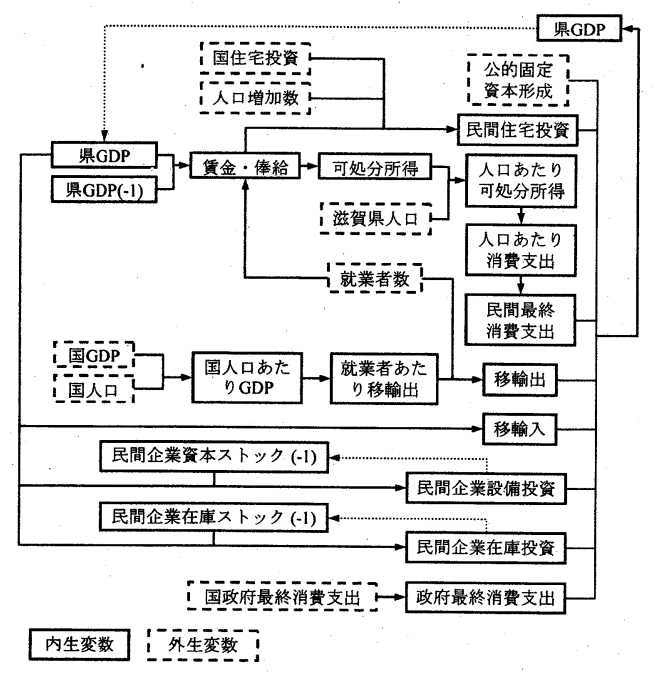

図-2 滋賀県マクロ計量経済モデルの構造

\section{4. スナップショットツールの開発}

\section{(1) 概要}

開発したスナップショットツールの計算体系を図-3に示す. 環境負荷は後に示す滋賀県への適用例のものである. 推計 の全体は,いくつかの基本的な变数を入力とし, 次々に係数 を乗じて各種の指標を算出する体系となっている. まず産業 生産額や交通需要量などを推計する.ここではこれらの指標 を社会経済指標と呼ぶことにする. 次いで, 社会経済指標と
利用技術の想定などから環境負荷排出量を推計する.

将来社会全体の状態に関する様々な想定は, 入力される 变数と, 社会経済指標推計の係数(例えば労働生産性の向 上率)の設定に反映される.これらの設定によって, 様々な状 況のもとでの環境負荷の排出量を推計することが出来る.

\section{(2) 推計の流れ}

具体的な推計の流れを説明する.

まず社会経済指標を推計する. 基本的な入力変数として, 人口・世帯数, 最終需要, 土地利用別土地面積を与え, 最 終需要から産業連関分析を利用して業種別の産業生産額を 推計する.ここでは最終需要コンバーターや投入係数が, 社 会経済の想定を反映した係数しして与えられる.ここで得られ た産業生産額力ら, 以下の各指標を推計する.

- 産業生産額と労働生産性から, 必要とされる労働時間を 求める.この労働時間を満たすように, 生活時間のうちの 「労働時間」を決定する.

- 貨物輸送需要量は産業生産額に生産額あたりの輸送需 要量を乗じて推計する.

・業務床面積は第三次産業の生産額に生産額あたりの床 面積を乗じて推計する(なお, 業種によっては人口要因 (学生数など)を利用する).

- 家畜飼養頭羽数は「農業」の生産額に生産額あたりの家 畜飼養頭习习数を乗じて推計する.

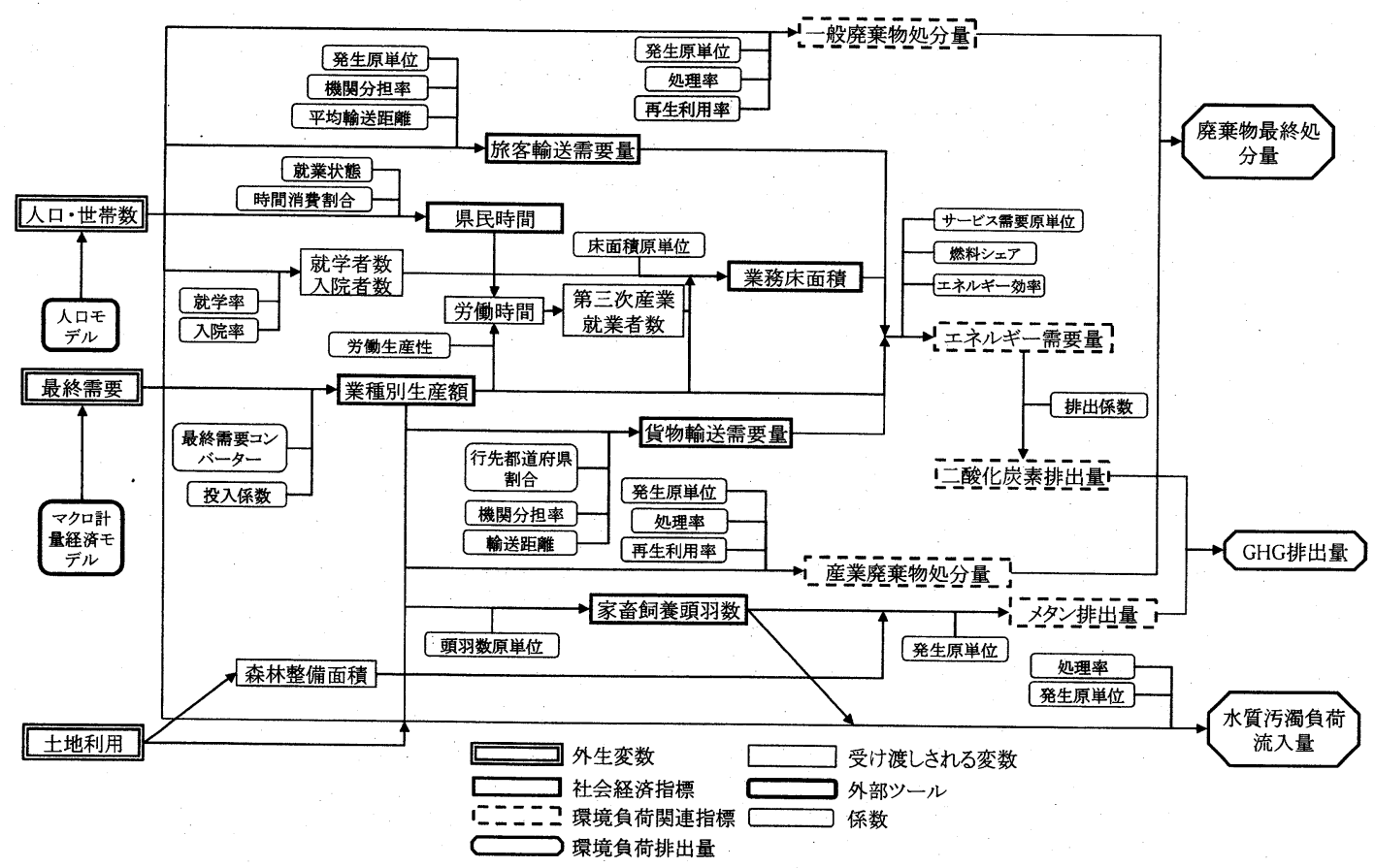

図-3 スナップショットツールの計算体系 
旅客輸送需要量は, 与えられた個人属性別の人口に各 種の係数(社会経済の想定から設定する)を乗じて推計する.

次に環境負荷の排出量を推計する. 上で推計した各種の 社会経済指標から, 対象とする環境負荷の発生に関わるも のを選択する.これを環境負荷を排出する各部門の「活動 量」と呼ぶ. 活動量に環境負荷の発生原単位などの係数を 乗じて環境負荷排出量を推計する. 環境対策の導入は主と してこれらの係数に反映される. 排出量が目標を満足するよ うなこれらの係数の值を求めることによって, 必要な対策導入 量を同定する.

\section{(3) 社会経済指標の推計}

\section{a) 産業生産額}

最終需要から, 業種別の産業生産額を推計する. 産業連 関分析を利用する. 対象期間の産業活動は次式で示される.
$X:$ 産業生産額べ外ル
$M$ : 移輸入額ベクトル
$A$ : 投入係数行列
$F$ :域内最終終需要額ベ外ル
$E:$ 移輸出額ベクトル

$X+M=A X+F+E$

式(1)を変形して次式を得る.

$$
X=(I-(I-\bar{M}) A)^{-1} \times((I-\bar{M}) F+E)
$$

ここで, $\bar{M}$ は移輸入率べ外ルで, $\bar{M}=M(X+F)$ である.こ れにより, 業種別の域内最終需要額, 移輸出額, 移輸入率, 投入係数行列から, 産業生産額ベ外ル $X$ が導かれる. なお, 以降の各式では,

$$
X=P D_{p d s}
$$

$P D_{p d s}:$ 産業生産額

$p d s$ :業種

として, 記号 $P D て ゙$ 産業生産額を表す.

\section{b) 生活時間}

将来社会の状態を表現する一側面として, 本研究では 様々な活動への県民の時間投入を表現する. 時間の使い方 は人々の「暮らしぶり」端的に現す指標のひとつである. ま た, 経済面から見れば, 労働時間は生産要素の供給である. 産業生産に必要な労働時間が供給されるといら整合性を確 認するためにも, 生活時間の推計は必要である.

一年間の県民の生活時間の合計を県民時間と呼ぶことに し, それは次式で表現される(本ツールは様々な自治体の単 位に適用可能だが, 便宜上, 対象自治体の住民を「県民」と 表記する).

$$
T I_{t c}=\sum_{s} \sum_{w} \sum_{\text {age }}\left(P O P_{s, w, a g e} \cdot T S_{s, w, a g e, t c}\right) \times 365.25 \times 24
$$

$T I_{k}:$ 県民時間
$P O P_{\text {swoge }}$ : 人口
$T S_{\text {swoggex }}$ :時間消費割合
$t c:$ 活動種
$s:$ 性別
$w$ :就業状態
$a g e:$ 年齢

ところで, 県民時間のうち「労働」は, 生産に必要な労働時 間を満たさなくてはならない. そこで, 次式が成立するよう労 働」の時間を決定する.

$$
T I_{W}=\sum_{p d s} P D_{p d s} \cdot M L P_{p d s}
$$

$T_{W}$ : 県民時間の「労働」

$M L P_{p b s}$ :労働係数

労働係数とは労働生産性の逆数で, 労働時間:生産額で ある.

\section{c) 業務床面積}

業務床面積の推計式を示す.

$$
F A_{c s}=P D_{c s} \cdot F A A_{c s}
$$

$F A_{c}$ : 業務床面積

$F A A_{c}:$ 活動量あたりの床面積

$c s$ : 業務部門業種

ここでの活動量とはそれぞれの業種の活動水準を示す指 標であり, 生産額を基本とする.ただし後に示す滋賀県への 適用にあたっては,「学校」では学生数,「病院」では入院患 者数で代替した.

\section{d) 旅客輸送量}

旅客輸送需要量の推計式を示す.

$$
\begin{aligned}
& P T D_{p t m}=\sum_{p} \sum_{p t p} P O P_{p} \cdot P T G_{p, p t p} \cdot M S_{p, p t p, p t m} \cdot A D_{p t p, p t m} \\
& P T D_{p m}: \text { 旅客輸送需要量 } \\
& P O P_{p}: \text { 人口 } \\
& P T G_{p p p}: \text { 旅行発生原単位 } \\
& M S_{p p p p m}: \text { 輸送機関分担率 } \\
& A D_{p p p o n}: \text { 平均輸送距離 } \\
& p: \text { :個人属性 } \\
& p t m: \text { :旅客輸送機関 } \\
& p t p: \text { 旅行目的 }
\end{aligned}
$$


ここで旅客輸送量を a)の産業連関分析とは別に推計する のは, 産業連関表の運輸部門にはマイカー輸送が含まれ ておらず，また県の公表する産業連関表では旅客と貨物 が分かれていないことから，生産額と旅客輸送量(人・ km)の関係が明らかでないためである.

\section{e) 貨物輸送量}

貨物輸送需要量の推計式を示す.

$$
F T D_{f t m}=\sum_{p d s} \sum_{d p} P D_{p d s} \cdot F T G_{p d s, d p} \cdot F T S_{p d s, f m, d p} \cdot F T A D_{f t m, d p}
$$

$$
F T D_{f m}: \text { 貨物輸送需要 }
$$

$P D_{p \phi}$ :生産額

$F T G_{p \bowtie s}:$ 貨物輸送発生原単位

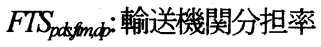

$F T A D_{f m, \phi}$ : 平均輸送距離

$d p:$ 行先都道府県

$f m:$ 貨物輸送機関

\section{f) 家畜飼養頭羽数}

家畜飼養頭羽数の推計式を示す.

$$
N L S_{l s}=P D_{a g r i} \cdot N P D_{l s}
$$

$N L S_{C S}$ : 家畜飼養頭习习数

$P D_{\text {agi }}$ : 産業生産額のうち「農業」

$N P D_{k}$ : 農業生産額あたり頭羽数

$l s$ : 家畜種

\section{（4）環境負荷排出量の推計方法}

環境負荷排出量の推計は, 基本的に次式による.

環境負荷排出量 $=$ 活動量 $\times$ 発生原単位 $\times$ 他の技術係数

環境負荷の種類は, ツールが適用される際の状況に応じ て選択される.「他の技術係数」には, 対象となる環境負荷の 種類によって様々なものが適用される. 例えば水質污濁負荷 物質は浄化施設による除去率, 廃棄物最終処分量では再生 利用率などが考えられる.「排出」される性質の環境負荷であ れば, 上式に適切な係数をあてはめることにより, 本ツールで 統一的に扱うことができる. 後に本ツールを滋賀県へ適用す るが, その際に対象とする各環境負荷の具体的な推計式を 以下に示しておく.

\section{a) エネルギー起源二酸化炭素}

エネルギー需要量と二酸化炭素排出量の推計式を示す. 表-1にエネルギー需要部門とその活動量, エネルギーサー ビス種の区分を示す. エネルギー利用技術は島田ら 3 のもの を利用した。

$$
\begin{aligned}
& E S D_{\text {eds,esc }}=A C_{\text {eds,esc }} \cdot E D G_{e d s, e s c} \\
& E E_{e d s, e s c, e}=\sum_{e t}\left(E E T_{e t, e d s, e s c, e} \cdot S E T_{e t, e d s, e s c, e}\right) \\
& E D_{e d s, e}=\sum_{e s c}\left(E S D_{e d s, e s c} \cdot E S_{e d s, e s c, e} \cdot E E_{e d s, e s c, e}\right) \\
& C \mathrm{O}_{2}=\sum_{e d s} \sum_{e}\left(E D_{e d s, e} \times E F_{e}\right) \\
& E S D_{\text {eksex }} \text { :エネルギーサービス需要量 } \\
& A C_{\text {eckec }} \text { : 活動量 }\left(P O P, P D_{p d \phi} F A, P T D_{p m n} F T D_{f n}\right) \\
& E D G_{\text {edsex }} \text { :エネルギーサービス需要原単位 } \\
& E E T_{\text {eteaserexe: }} \text { :エネルギー利用技術の効率 } \\
& S E T_{\text {etectexe: }} \text { :エネルギー利用技術のシェア } \\
& E D_{\text {edse }} \text { :エネルギー需要量 } \\
& E S_{\text {eatexe: }} \text { :然料シェア } \\
& E E_{\text {eateece }}: \text { エネルギー効率 } \\
& \mathrm{CO}_{2} \text { : 二酸化炭素排出量 } \\
& E F_{e}: \text { 二酸化炭素排出係数 } \\
& e d s: \text { エネルギー需要部門 } \\
& \text { esc:エネルギーサービス種 } \\
& \text { et:エネルギー利用技術s } \\
& e: \text { 燃料種 }
\end{aligned}
$$

\begin{tabular}{|c|c|c|}
\hline 部門 & 活動量 & エネルギーサービス種 \\
\hline 家庭 & 世帯数 & $\begin{array}{l}\text { 冷房, 暖房, 給湯, 㕌房, } \\
\text { その他 }\end{array}$ \\
\hline 業務 & 床面積 & $\begin{array}{l}\text { 冷房, 暖房, 給湯, 厨房, } \\
\text { その他 }\end{array}$ \\
\hline 産業 & 生産額 & 業種別 \\
\hline 旅客 & $\begin{array}{l}\text { 輸送需要量 } \\
(人 \cdot \mathrm{km})\end{array}$ & $\begin{array}{l}\text { 輸送機関別(鉄道, バス, 乗 } \\
\text { 用車, 二輪車, 自転車, 徒 } \\
\text { 歩, その他) }\end{array}$ \\
\hline
\end{tabular}

表-1 エネルギー需要部門の区分

貨物 輸送需要量 輸送機関別(鉄道, 船舶, 自 $(\mathrm{t} \cdot \mathrm{km})$ 家用貨物車, 営業用貨物車)

\section{b) 農業起源メタン}

農業起源のメタンの排出源は, 水田, 牛, 豚の消化管発酵 および牛, 豚, 鶏のし尿処理である. 活動量は面積およひ頭 羽数である.これにメタンの排出係数を乗じて算出する.

$$
\mathrm{CH}_{4}=\sum_{\text {mes }} A C_{\text {mes }} \times N R G_{\text {mes }}
$$

$\mathrm{CH}_{4}$ : X夕ン排出量

$A C_{\text {mes }}$ 活動量 $\left(N L S_{\mathrm{s}}\right.$ 水田面積)

mes: 夘排出部門(牛, 豚, 鳥, 水田)

\section{c) 水質污濁負荷流入量}

対象地域である滋賀県においては, 琵琶湖の水質保全が 
環境保全において重要な課題である. そこで琵琶湖への水 質污濁負荷流入量を推計することとした. その推計式を示す.

$N R I_{n c}=\sum_{n r s} A C_{n r s} \times N R G_{n r s, n c} \times C R_{n r s, n c}$

$N R I_{n}$ :水質污濁負荷流入量

$A C_{m}$ : 活動量 $(P O P, P D p d s, N L S l s$, 土地利用面積)

$N R G_{m \times x}$ : 水質污濁負荷発生原単位

$C R_{n \leq x}:$ 水質污濁負荷除去率

$n r s:$ 水質污濁負荷排出部門

(生活, 産業, 農業, 土地利用)

$n c:$ 水質污濁負荷種

(化学的酸素要求量, 総窒素, 総リン)

\section{d) 廃棄物最終処分量}

一般廃棄物, 産業廃棄物ともに同一の枠組みで推計する. 活動量は産業生産額と人口である.

$$
\begin{aligned}
& W_{w g s, w c}=A C_{w g s} \times W G_{w g s, w c} \\
& W P_{w c, w p d r}=\sum_{w g s} W_{w g s, w c} \times W P S_{w c, w p d r}
\end{aligned}
$$

$W_{\text {wgswe }}$ :廃棄物排出量

$A C_{\text {wgs }}$ : 活動量 $\left(P O P, P D_{p d s}\right)$

$W G_{\text {wgswc }}$ : 廃棄物排出原単位

$W P_{\text {wcwpd }}:$ 廃棄物処理処分量

$W P S_{\text {wcupd }}$ : 処理処分率

$w g s:$ 廃棄物排出部門

$w c$ :廃棄物種

$w p d r:$ 処理処分方法

(中間処理, 再生利用, 最終処分)

\section{5.滋賀県への適用}

\section{(1) 目標と枠組み}

対象地域は滋賀県, 基準年は 2000 年, 目標年は 2030 年 とした. 環境の目標は, 滋賀県庁および関連研究機関等へ のヒアリングの結果, 以下の三項目を定めた. 温室効果ガス (二酸化炭素排出量, メタン排出量), 水質污濁負荷流入量 (化学的酸素要求量 (COD), 総窒素(TN), 総少 $(\mathrm{TP})$ ), 廃菓物 最終処分量(一般廃棄物, 産業廃棄物)である.

温室効果ガス排出量の目標については, 産業化以前から の温度上昇を $2^{\circ} \mathrm{C}$ 以内に抑制して気候を安定化することで 合意が形成されつつある.これを達成するために日本に求め られる排出量の水準として, 近年の研究は今世紀半ば頃ま でに 1990 年比で 60-80\%の排出削減が必要としている212).こ こでの目標年は 2030 年なので, 2050 年への中間目標として 温室効果ガス排出量の目標を 1990 年比で $50 \%$ 削減とした.

琵琶湖の水質は, 北湖で赤潮やアオコが発生する以前の 水質レベル(昭和 40 年代の水質(COD1.7mg/))を目標とした. そのためには，琵琶湖への水質污濁負荷流入量を 2000 年 比で半減する必要があるとされている ${ }^{13)}$. そこで, COD, TN, TPの流入量を 2000 年比で $50 \%$ 削減することを目標しした。

廃棄物最終処分量については, 滋賀県第二次廃棄物処 理計画 ${ }^{14}$ において, 一般廃棄物, 産業廃棄物の 2010 年度の 最終処分量を，それぞれ 1997年度の 1/2，1/3にすることを目 標ししている.ここではその目標を延長し，両者を合わせた最 終処分量を 1997 年比 $80 \%$ 削減(2000年比 75\%削減)とした.

\begin{tabular}{|c|c|c|c|}
\hline 項目 & 設定 & $\begin{array}{l}\text { 関連する社会経済の } \\
\text { 想定 } \\
\end{array}$ & $\begin{array}{c}\text { 出典・ } \\
\text { 基準年データ }\end{array}$ \\
\hline 人口 & 2030 年に 138 万人(滋賀県による 2006 年の推計. 2005 年とほぼ同じ) & & 15) \\
\hline 世帯数 & 2030 年に 52 万世帯(同上. 2005 年は 47 万世帯) & & 15) \\
\hline 日本経済 & 一人当たり GDP 年平均 約 $0.9 \%$ で成長 & $\begin{array}{l}\text { 成熟型の経済 } \\
\text { 比較的緩やかな技術 } \\
\text { 革新速度 }\end{array}$ & 16) \\
\hline 公的固定資本 & $\begin{array}{l}\text { 社会資本整備などの投資. 社会資本整備が一巡し, 新規整備は大幅に減少し, 維持管理 } \\
\text { を主とした資本投資. 総投資額は現状より減少. }\end{array}$ & 成熟型の経済 & 17) \\
\hline 民間消費支出 & 主に家計における消費の財・サービス毎の内訳. 製品の長寿命化が進み, モノの購入金額 & 第三次産業の割合増 & \\
\hline の内訳 & $\begin{array}{l}\text { は横ばいに推移. 農林水産業, 個人向けサービス(教育, 医療·保険, 旅館·宿泊所など)に } \\
\text { 対する支出の割合が上犁すると想定. }\end{array}$ & 加, 高齢化の進行 & 17) \\
\hline 移出の内訳 & $\begin{array}{l}\text { 滋賀県から移出する財・サービスの内訳. 製造業製品の移出額は金額ベース横這いに推 } \\
\text { 移すると想定 }\end{array}$ & $\begin{array}{l}\text { 第三次産業の割合増 } \\
\text { 加 }\end{array}$ & 17) \\
\hline 移入率 & 農林水産業製品の移入率は低下.その他の財やサービスの移入は増加. & 地産地消の促進 & 17) \\
\hline 投入係数 & $\begin{array}{l}\text { IT普及によるペーパーレス化, 公共事業における金属, セメント投入の減少·木製品利用 } \\
\text { の増加, 省エネによる燃料, 電力消費の減少を想定. }\end{array}$ & & 17) \\
\hline 労働生産性 & 労働者 1 人 1 時間あたりの労働生産性 :農業.製造業 $2.7 \%$ 年, サービス業 $1.6 \%$ 年向上. & & 17)18) \\
\hline 生活時間 & 男性就業者の労働時間 1.5 時間短縮. 男性女性ともに社会活動参加時間増加と想定. & $\begin{array}{l}\text { ゆとり, 仕事と生活の } \\
\text { バランス, 社会貢献 }\end{array}$ & 19) \\
\hline 就業率 & $\begin{array}{l}\text { 高齢者や女性が働くことができる福祉環境が整備され, 男性高齢者の就業率 } 20 \% \text { 上昇, } \\
\text { 女性の就業率 } 10 \sim 30 \% \text { 上昇. }\end{array}$ & 仕事と生活のバランス & 20) \\
\hline
\end{tabular}

表-2 将来推計の主な想定 


\section{(2) 将来の社会経済像之係数の設定}

将来の社会経済像は, 成熟型で比較的「ゆとり」のあ社 会の状態を想定した. 一人あたりの一日の就業時間は短縮 され, 仕事と生活のバランスをとり, 社会へ貢献しながら生活 全体として充実した時間を送ることが良しとされる. 産業では 第三次産業の割合が高まる. 高齢化の進行により介護等の サービス業の需要が高まり, 同時に高齢者の就業も求められ る. 農産物の地産地消がす寸む. 家族やコミュニティの連帯 が重視される. 技術革新の速度は比較的緩やかである.この ような社会イメージに基づいて設定した, 県人口, 国経済成 長率, 消費の傾向, 生活時間と労働などの值, 各種係数と, その基準年データ, および推計年の值の設定方法を表-2に 示寸.

\section{(3) 社会経済指標の推計結果}

滋賀県の一人あたり GDPの成長率は年平均 $0.90 \%$ と推計 された. 2030年の産業生産額は 2000 年の 1.16 倍(13.4 兆円) となった. 第一次, 第二次, 第三次産業の生産額はそれぞれ 2000 年の 5.91 倍, 0.90 倍, 1.50 倍となった. 交通構造が 2000 年と変化しないと仮定した場合, 旅客輸送量は人口要因の 変化(移動距離の長い 15 歳以上の人口の割合増加, 女性 の免許保有率向上による自動車による移動の増加など)から， 2000 年の 1.53 倍に増加して 16359 百万人 $\cdot \mathrm{km}$ となった. 貨 物輸送量は産業構造の変化から 0.86 倍に減少し 3397 百万 $\mathrm{t} \cdot \mathrm{km}$ となった. 業務床面積は第三次産業の生産額増などか ら2000年の 1.13 倍に増加して 22667 千 $\mathrm{m}^{2}$ となった。

\section{（4) 環境負荷排出量推計の結果と考察}

\section{a) 温室効果ガス}

温室効果ガス排出量の推計結果を図-4に示す. 2030 年の 温室効果ガス排出量は対策導入を想定しない場合(図-4の 「2030BaU」), $14369 \mathrm{ktCO}_{2} \mathrm{eq}$ となり, 1990 年から 15\%の増加と なる. 排出部門では産業部門からの二酸化炭素排出量が最 も多く, 6436ktCO で全体の 44.8\%を占めている. 対策を導入 した場合(「2030対策」), 全体の排出量は $6276 \mathrm{ktCO}$ eq となり, 1990 年比で $50 \%$ の排出削減が可能となった。 対策の分類別の削減量を表-3に示す.「効率改善」が 37\% で最も多くを占めた. また, 特に地方自治体の政策が重要に なると考えられる,「再生可能エネルギー」環境配慮行動」 「交通構造改革「森林吸収」の合計は $31 \%$ となった。これらを 推進する地方独自の政策が必要であることが示された。

\section{b) 水質污濁負荷}

表-4に水質污濁負荷流入量の推計結果を示す. 2030 年 において表-8の対策を想定した結果, COD7.6t(2030 年の 47\%), TN3.4t(同 50\%), TP0.094(同 22\%)となった. いずれも設 定した目標(2000年の $50 \%)$ を達成することが示された.
用からの排出が $8.0 \mathrm{kt}$ と約半分を占めており, 目標の達成に は土地利用からの排出削減が必要になる. それには, 市街 地排水浄化といった社会基盤整備だけでなく, 水田の反復 灌溉, 森林管理のような自然系の土地利用への対策が必要 になる.

表-3 対策分類別の二酸化炭素排出削減量( $\left(\mathrm{k} 1 \mathrm{CO} \mathrm{O}_{2} \mathrm{aq}\right)$

\begin{tabular}{lrr}
\hline 対策分類 & 排出削減量 & 割合 \\
\hline 電源構成 & 1687 & $21 \%$ \\
効率改善 & 3008 & $37 \%$ \\
燃料転換 & 967 & $12 \%$ \\
再生可能エネルギー & 615 & $8 \%$ \\
環境配慮行動 & 880 & $11 \%$ \\
交通構造変革 & 459 & $6 \%$ \\
森林吸収 & 477 & $6 \%$ \\
合計 & 8094 & $100 \%$ \\
\hline
\end{tabular}

※排出削减量は 2030BaU排出量に対しての削减量である

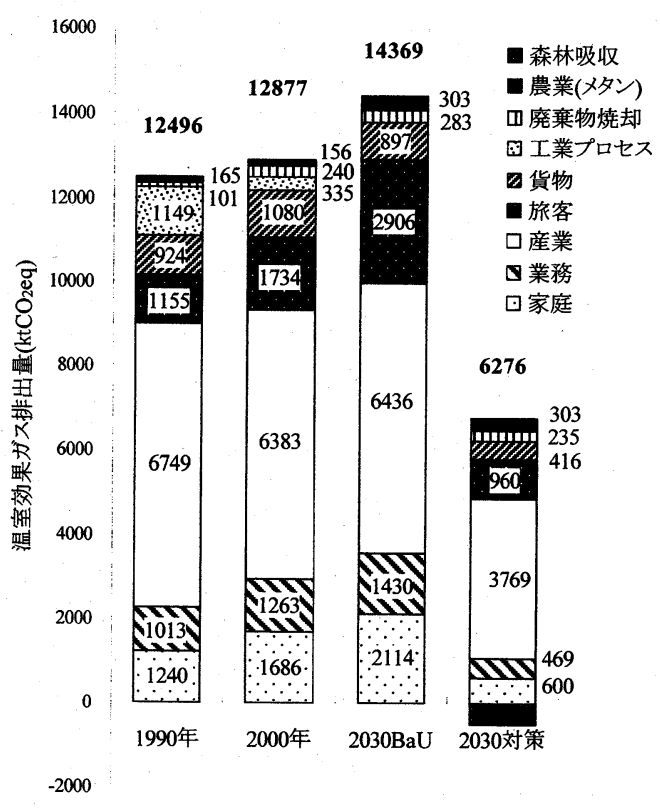

図-4 温室効果ガス排出量の推計結果

「工業プロセス」は, 滋賀県地球温暖化対策推進計画2》による.

\begin{tabular}{lrrrrrr}
\multicolumn{7}{c}{ 表-4水質污濁負荷流入量 $(\mathrm{kt})$} \\
\hline & \multicolumn{7}{c}{ COD } & \multicolumn{2}{c}{$\mathrm{TN}$} & \multicolumn{1}{l}{ TP } \\
排出部門 & 2000年 & 2030年 & 2000年 & 2030年 & 2000年 & 2030年 \\
\hline 湖面降雨 & 1.9 & 1.6 & 0.7 & 0.6 & 0.02 & 0.02 \\
地下水 & 0.1 & 0.1 & 0.4 & 0.4 & 0.02 & 0.02 \\
土地利用 & 8.0 & 4.4 & 3.0 & 0.9 & 0.12 & 0.02 \\
畜産 & 0.6 & 0.7 & 03 & 0.4 & 0.02 & 0.007 \\
事業所 & 1.6 & 03 & 0.6 & 0.2 & 0.05 & 0.01 \\
生活 & 4.0 & 0.5 & 1.8 & 0.9 & 0.16 & 0.01 \\
合計 & 162 & 7.6 & 6.8 & 3.4 & 0.39 & 0.087 \\
\hline
\end{tabular}




\section{c) 廃棄物}

廃棄物最終処分量は, 表-9の対策のもとで, 一般廃棄物 が 23kt(表-5), 産業廃棄物が 71kt(表-6)となり, ともに目標で ある2000年の $25 \%$ となった。一般廃棄物では分別収集によ り, 再生利用量と集団回収量の合計の割合が 2000 年の $13 \%$ から 2030 年には $81 \%$ へと大幅に引き上げる必要がある.これ
には住民の協力が必要である. 産業廃棄物では再生利用量 と有償物量の合計の割合を約 $13 \%$ 増加させることで目標が 達成されている. 産業廃棄物では 2000 年から 2004 年までに 最終処分量がほぼ半減しており,ここでの結果はこの延長上 にあるものといえる。

\begin{tabular}{|c|c|c|c|c|}
\hline & 発生量 & & 割合 & \\
\hline & 2000 年 & 2030 年 & 2000 年 & 2030 年 \\
\hline 自家処理量 & 4.9 & 0.4 & $1.0 \%$ & $0.1 \%$ \\
\hline 减量化量 & 345 & 60 & $67.7 \%$ & $13.5 \%$ \\
\hline 再生利用量 & 39 & 260 & $7.6 \%$ & $58.5 \%$ \\
\hline 集団回収量 & 29 & 101 & $5.7 \%$ & $22.7 \%$ \\
\hline 最終処分量 & 92 & 23 & $18.0 \%$ & $5.2 \%$ \\
\hline 合計 & 510 & 444 & $100.0 \%$ & $100.0 \%$ \\
\hline
\end{tabular}

表-6 産業廃棄物の推計結果(kt)

\begin{tabular}{lrrrr}
\hline & 発生量 & & 割合 & \\
& 2000 年 & 2030 年 & 2000 年 & 2030 年 \\
\hline 減量化量 & 1894 & 2371 & $47.4 \%$ & $47.3 \%$ \\
有償物量 & 156 & 259 & $3.9 \%$ & $5.2 \%$ \\
再生利用量 & 1664 & 2315 & $41.6 \%$ & $46.2 \%$ \\
最終処分量 & 286 & 71 & $7.2 \%$ & $1.4 \%$ \\
合計 & 4000 & 5016 & $100.0 \%$ & $100.0 \%$ \\
\hline
\end{tabular}

表-7 温室効果ガスの削減対策とその効果 $\left(\mathrm{ktCO}_{2}\right)$

\begin{tabular}{|c|c|c|c|c|}
\hline \multirow{2}{*}{ 部門 } & \multirow{2}{*}{ 対策 } & \multirow{2}{*}{2030 年の対策導入量 } & \multicolumn{2}{|c|}{ 排出削減量※ } \\
\hline & & & 削减量 & 割合 \\
\hline \multirow[t]{5}{*}{ 家庭 } & 機器のエネルギー効率改善 & 全体で $30 \%$ の効率改善 & 551 & $6.8 \%$ \\
\hline & 省エネルギー行動 & ほぼ全ての家庭に普及 & 156 & $1.9 \%$ \\
\hline & 太陽光発電 & 20\%の住宅に普及 & 54 & $0.7 \%$ \\
\hline & その他 & & 383 & $4.7 \%$ \\
\hline & 家庭計 & & 1144 & $14.1 \%$ \\
\hline \multirow[t]{5}{*}{ 業務 } & 機器のエネルギー効率改善 & 全体で 36\%の効率改善 & 443 & $5.5 \%$ \\
\hline & 省エネルギー行動 & ほぼ全ての事業所に普及 & 43 & $0.5 \%$ \\
\hline & 太陽光発電 & 15\%の建物に設置 & 12 & $0.1 \%$ \\
\hline & その他 & & 176 & $2.2 \%$ \\
\hline & 業務計 & & 674 & $8.3 \%$ \\
\hline \multirow[t]{3}{*}{ 産業 } & 機器のエネルギー効率改善 & 全体で 28\%の効率改善 & 846 & $10.5 \%$ \\
\hline & 燃料シェア転換 & $\begin{array}{l}\text { 天然ガス: } 2000 \text { 年 } 8.6 \% \rightarrow 25.9 \% \\
\text { 電力: } 2000 \text { 年 } 30.9 \% \rightarrow 33.7 \%\end{array}$ & 883 & $10.9 \%$ \\
\hline & 産業計 & & 1729 & $21.4 \%$ \\
\hline \multirow[t]{7}{*}{ 旅客輸送 } & コンパクトシティ & 地域内の平均移動距離が $25 \%$ 減 & 215 & $2.7 \%$ \\
\hline & 自動車の燃費改善 & 乗用車の平均燃費が 1.6 倍向上 & 788 & $9.7 \%$ \\
\hline & 公共交通 自転車・徒歩 & 鉄道のシェアが 36\%(2000 年 31\%) & 633 & $7.8 \%$ \\
\hline & & 自転車・徒歩の合計シェアが $16 \%$ & & \\
\hline & バイオマス燃料 & 普及率 $10 \%$ & 193 & $2.4 \%$ \\
\hline & その他 & & 36 & $0.4 \%$ \\
\hline & 旅客計 & & 1865 & $23.0 \%$ \\
\hline \multirow[t]{5}{*}{ 貨物輸送 } & 物流合理化 & 生産額あたりの輸送量が 3割减 & 51 & $0.6 \%$ \\
\hline & モーダルシフト & $\begin{array}{l}\text { 遠県へのトラック輸送の } 50 \% \text { が鉄道へ } \\
\text { 県内の } 10 \% \text { 湖運へ }\end{array}$ & 194 & $2.4 \%$ \\
\hline & バイオマス燃料 & 普及率 $10 \%$ & 75 & $0.9 \%$ \\
\hline & その他 & & 150 & $1.9 \%$ \\
\hline & 貨物計 & & 470 & $5.8 \%$ \\
\hline \multirow[t]{3}{*}{ その他 } & 電力原単位の低减 & 国全体の電力構成の変化と発電の効率改善 & 1687 & $20.8 \%$ \\
\hline & 森林整備 & 滋賀県の人工林全てを管理 & 477 & $5.9 \%$ \\
\hline & 廃棄物リサイクル & プラスチックのリサイクル率を $36 \%$ 向上 & 48 & $0.6 \%$ \\
\hline 削減量計 & . & & 8094 & $100 \%$ \\
\hline
\end{tabular}

※排出削减量は 2030BaU 排出量に対しての削减量である 
表-8 水質污濁負荷流入量の削減対策とその効果(kt)

\begin{tabular}{|c|c|c|c|c|c|}
\hline \multirow{2}{*}{ 部門 } & \multirow{2}{*}{ 対策 } & \multirow{2}{*}{2030 年の導入量 } & \multicolumn{3}{|c|}{ 削減量 } \\
\hline & & & COD & $\mathrm{TN}$ & TP \\
\hline \multirow[t]{4}{*}{ 生活 } & 下水道整備 & 琵琶湖集水域内の下水道普及率が 96\%に & 1.78 & 0.42 & 0.09 \\
\hline & 棏房管理 & 全家庭に普及 & 1.40 & 0.29 & 0.04 \\
\hline & その他 & & 0.38 & 0.11 & 0.02 \\
\hline & 生活計 & & 3.56 & 0.82 & 0.15 \\
\hline \multirow[t]{3}{*}{ 産業 } & 下水道への接続処理 & すべて下水道に接続 & 0.67 & 0.15 & 0.03 \\
\hline & 家畜屎尿の農地還元利用 & 適用率 $100 \%$ & 0.02 & 0.01 & 0.01 \\
\hline & 産業計 & & 0.68 & 0.15 & 0.04 \\
\hline \multirow[t]{7}{*}{ 土地利用 } & コンパクトシティ & 建物用地, 荒地, 道路のうち 20\%を緑地に転用 & 0.23 & 0.04 & 0.00 \\
\hline & 市街地排水浄化施設 & 30\%の市街地排水を処理 & 0.15 & 0.02 & 0.00 \\
\hline & 施肥量の削減 & 全ての農地で実施 & 0.00 & 0.23 & 0.02 \\
\hline & 排水反復利用 & 水田への適用率 50\% & 0.56 & 0.09 & 0.00 \\
\hline & 適切な間伐など森林の適正管理 & 人工林全てで実施 & 0.47 & 0.19 & 0.00 \\
\hline & その他 & & 0.39 & 0.07 & 0.00 \\
\hline & 土地利用計 & & 1.80 & 0.64 & 0.04 \\
\hline \multirow[t]{2}{*}{ 河川 } & 河川直接浄化 & 土地利用からの排水のうち 50\%を浄化 & 0.46 & 0.14 & 0.01 \\
\hline & 多自然型の河川整備 & 整備対象となる全ての河川に適用 & 0.92 & 0.27 & 0.01 \\
\hline その他 & & & 1.17 & 1.37 & 0.06 \\
\hline 削減量計 & & & 8.60 & 3.40 & $\mathbf{0 . 3 0}$ \\
\hline
\end{tabular}

※排出削減量は 2000 年流入量に対しての削減量である

表-9 廃棄物最終処分量の削減対策

\begin{tabular}{|c|c|c|c|}
\hline \multirow{2}{*}{ 廃棄物種 } & \multirow{2}{*}{ 対策 } & \multicolumn{2}{|c|}{ 資源化率 } \\
\hline & & 2000年 & 2030 年 \\
\hline \multirow[t]{3}{*}{ 一般廃棄物 } & 分別により再生利用量増加 & $7.6 \%$ & $58.5 \%$ \\
\hline & 分別により集団回収量増加 & $5.6 \%$ & $22.7 \%$ \\
\hline & レンタル・リースの活用による発生量の減量 & \multicolumn{2}{|c|}{ 発生量を $10 \%$ 削減 } \\
\hline \multicolumn{4}{|l|}{ 産業廃棄物 } \\
\hline $\begin{array}{l}\text { 廃プラスチック・ } \\
\text { ゴムくず }\end{array}$ & $\begin{array}{l}\text { 合成樹脂, 合成ゴム, 廃タイヤのマテリアル } \\
\text { サーマルリサイクル }\end{array}$ & $75.7 \%$ & $94.0 \%$ \\
\hline 木くず & $\begin{array}{l}\text { 木材利用, ボード等の建材に加工, 炭化・ガス } \\
\text { 化, 化学処理, 肥料化・飼料化 }\end{array}$ & $92.2 \%$ & $98.0 \%$ \\
\hline $\begin{array}{l}\text { ガラスくず・・ } \\
\text { 陶磁器くず }\end{array}$ & $\begin{array}{l}\text { カレット化, ガラスビン再利用, タイル・ブロ } \\
\text { ック, 超軽量骨材, アスファルト舗装材 }\end{array}$ & $81.4 \%$ & $92.0 \%$ \\
\hline がれき類 & $\begin{array}{l}\text { 建設廃棄物の選別・再資源化，建設発生土の再 } \\
\text { 利用，道路舗装材用 }\end{array}$ & $97.8 \%$ & $99.0 \%$ \\
\hline
\end{tabular}

表-10 目標達成のために各主体のとるべき行動

\begin{tabular}{|c|c|c|c|}
\hline & $\begin{array}{c}\text { 温室効果ガス } \\
1990 \text { 年比 } 50 \% \text { 削減 }\end{array}$ & $\begin{array}{l}\text { 水質污濁負荷流入量 } \\
2000 \text { 年比 } 50 \% \text { 削減 }\end{array}$ & $\begin{array}{l}\text { 廃棄物最終処分量 } \\
2000 \text { 年比 } 75 \% \text { 削减 }\end{array}$ \\
\hline 事業者 & $\begin{array}{l}\text { 排出削減量: } 2873 \mathrm{ktCO} \mathrm{CO}_{2} \mathrm{eq} \\
\text { 高効率製造機器の導入, 製 } \\
\text { 造·輸送用燃料の転換, 物流 } \\
\text { 合理化·モーダルシフト }\end{array}$ & $\begin{array}{l}\text { 排出削减量: COD 1.24kt, TN 0.48kt, TP 0.06kt ※2 } \\
\text { 生産額あたりの水質污濁負荷発生減少, } \\
\text { 排出の少ない農法 }\end{array}$ & $\begin{array}{l}\text { 資源化率:13\%向上 } \\
\text { 廃棄物の資源化, 効率 } \\
\text { のよい資源化工場の整 } \\
\text { 備 }\end{array}$ \\
\hline 生活者 & $\begin{array}{l}\text { 排出削減量: } 2794 \mathrm{ktCO}_{2} \mathrm{eq} \\
\text { 環境こだわり住宅, 低燃費乗用 } \\
\text { 車の普及, 省エネ行動, 鉄道· } \\
\text { 自転車·徒歩利用 }\end{array}$ & $\begin{array}{l}\text { 排出削減量: COD 2.18kt, TN 0.46kt, TP 0.07kt } \\
\text { 旡房管理, 風呂水・雨水の再利用 }\end{array}$ & $\begin{array}{l}\text { 資源化率: } 81 \% \\
\text { レンタル・リース利用に } \\
\text { よる一般廃棄物の発生 } \\
\text { 抑制, 一般廃棄物の分 } \\
\text { 別·資源化 }\end{array}$ \\
\hline $\begin{array}{l}\text { 地方公共 } \\
\text { 団体等 }\end{array}$ & $\begin{array}{l}\text { 排出削減量:2427 } \mathrm{ktCO}_{2} \mathrm{eq} \\
\text { 森林整備, コンパクトシティの形 } \\
\text { 成, モーダルシフトの誘導 }\end{array}$ & $\begin{array}{l}\text { 排出削減量: COD 5.18kt, TN } 2.46 \mathrm{kt}, \mathrm{TP} 0.18 \mathrm{kt} \\
\text { 下水道整備と産業排水受入, 市街地排水対 } \\
\text { 策, 河川直接浄化·浚渫 }\end{array}$ & $\begin{array}{l}\text { 一般廃棄物の資源化· } \\
\text { 再利用システムの構 } \\
\text { 築, 効率の良いリサイク } \\
\text { ルルートの構築 }\end{array}$ \\
\hline
\end{tabular}




\section{6. まとめ}

本研究では, 地方自治体を対象として社会経済指標 と環境負荷排出の状態を定量的かつ整合的に表現す る統合推計ツールを開発した. その適用例として, 2030 年の滋賀県を対象として環境負荷排出量に関する推計 を行い, 環境の目標を達成するために必要な環境対策 の導入量を同定した.各主体に必要な行動を表-10に整 理して示す. 地方自治体として特に注目すべき対策は,

- 温室効果ガス: 再生可能エネルギ一普及, 環境配慮 行動, コンパクトシティ形成, モーダルシフト誘導, 吸 収源の森林整備.これらで全削減量の $31 \%$ 占める.

- 水質污濁負荷: 市街地排水浄化施設の整備, 農地 からの排出を減らす農法の普及. これらの COD の流 入削減量は下水道整備による削減量を上回る.

- 廃棄物最終処分量:分別収集に住民の協力を得るこ と. 一般廃棄物の再生利用率を大幅に引き上げる (約 6 倍)必要がある.

このような定量的な情報は, 環境に関する長期計画 を策定しようとする際に必須のものと考えられる．本研 究で開発した推計ツールを活用することで，より具体的 かつ効果的な議論が可能になるであろう.

\section{謝辞}

本研究にあたり, 岡山大学大学院の藤原健史教授, みずほ情報総研の日比野剛氏, 滋賀県琵琶湖・環境科 学研究センターの金再奎研究員のご協力を頂いた. ま た, 本研究は, 環境省地球環境総合研究推進費 S-3-1 「温暖化対策評価のための長期シナリオ研究」による研 究成果の一部である.ここに記して感謝の意を表す.

\section{参考文献}

1) Scenario Study Team of "Low Carbon Society Scenarios toward 2050": Development of Japan Low Carbon Society Scenarios, 2006.

2)「2050 日本低炭素社会」プロジェクトチーム: 2050 日本低 炭素社会シナリオ:温室効果ガス $70 \%$ 削减可能性検討, 2007.

3) 島田幸司, 田中吉隆, 五味馨, 松岡譲: 低炭素社会に向け た長期的地域シナリオ形成手法の開発と滋賀県への先駆 的適用, 環境システム研究, Vol. 34, pp. 143-154, 2006.
4) Greater London Authority: Action Today to Protect Tomorrow, London, 2007.

5) California Environmental Protection Agency: Climate Action Team Report to Governor Schwarzenegger and the Legislature, California Environmental Protection Agency, 2006.

6) Connecticut Governor's Steering Committee on Climate Change: Connecticut Climate Change Action Plan 2005 Executive Summary, 2005.

7) Governor's Advisory Group On Global Warming: Oregon's Strategy for Greenhouse Gas Reductions, 2004.

8) Environment and Health Administration of City of Stockholm: Stockholm's action program against Greenhouse Gases, 2002.

9) Öko institute e.V.: Local strategies for the reduction of the emissions around $50 \%$ by the example of the city of Munich, 2004.

10) Berlin21: Designing the FUTURE Agenda draft summary adopted byt the Berlin Agenda forum, 2004.

11) IPCC: Special Report on Emissions Scenarios, Cambridge, London, 2000.

12) 松岡 譲: 危険な気候変化のレベルと気候変動政策の長 期目標, 環境研究, Vol. 138, pp 7-16, 2005.

13) 滋賀県持続可能社会研究会: 持続可能社会の実現に向 けた滋賀シナリオ, 2007.

14) 滋賀県: 第二次廃棄物処理計画, 2006.

15)「しが 2030 の姿」検討ワーキンググループ:「みんなで描く しがの未来」, 2006.

16) 村上 正晃: 計量経済モデルを用いた日本における長期的 な二酸化炭素排出量の推計に関する研究, 京都大学修士 論文, 2006.

17) 滋賀県政策調整部統計課: 平成 12 年滋賀県産業連関表, 2005.

18) 総務省統計局: 平成 13 年事業所·企業統計調査, 2001.

19) 総務省統計局: 平成 13 年社会生活基本調査, 2003.

20) 総務省統計局: 平成 12 年国勢調査, 2000 .

21)加用千裕, 天野耕二, 島田幸司: 長期的炭素収支に基づ く日本国内の森林経営手法の評価, 環境システム研究, Vol. 34, pp. 235-243, 2006.

22) 滋賀県: 滋賀県地球温暖化対策推進計画[改訂版], 2006.

\section{DEVELOPMENT OF INTEGRATED ESTIMATION TOOL FOR MUNICIPALITIES AND ITS APPLICATION TO SHIGA PREFECTURE}

\section{Kei GOMI, Koji SHIMADA and Yuzuru MATSUOKA}

Municipalities need quantitative information that spans decades in order to address environmental issues effectively. We have developed a tool to estimate a snapshot of socio-economic condition and environmental load quantitatively and consistently. Based on assumptions of future society, it calculates socio-economic index such as production and transport demand. Given those index and assumptions of utilized technologies, it estimates environmental load. Treating more than one environmental load by identical framework, the tool also can respond various issues which a municipality faces. We also have applied the tool to Shiga prefecture with three environmental targets, GHG emission, nutrient influent to Lake Biwa and final disposal of waste. In the snapshot, all the targets are met in the year 2030. This tool will contribute to make the discussion about long term environmental plan more efficient and effective. 